\section{Temporary Covers Maintain Fall Bermudagras Quality, Enhance Spring Greenup, and Increase Stem Carbohydrate Levels}

\author{
J.M. Goatley, Jr., ${ }^{1}$ V.L. Maddox, ${ }^{2}$ D.L. Lang, ${ }^{3}$ R.E. Elmore, ${ }^{4}$ and \\ B.R. Stewart ${ }^{5}$ \\ Department of Plant and Soil Sciences, Mississippi State University, Mississippi \\ State, Mississippi 39762
}

Additional index words. Cynodon dactylon x transvaalensis, winterkill, turf blanket

\begin{abstract}
The ability of a temporary turf cover and foliar-applied iron (Fe) to sustain or promote bermudagrass (Cynodon dactylon (L.) $\times$ transvaalensis Burtt-Davy 'Tifway' growth beyond its normal growing periods in central Mississippi was evaluated during the fall, winter, and spring seasons of 1998-2001. The application of a polypropylene turf blanket when night temperatures were predicted to be $\leq 4{ }^{\circ} \mathrm{C}$ extended acceptable bermudagrass turf quality by 5 to 8 weeks in the fall and winter period as compared to the uncovered control plots. Also, complete green-up of the turf occurred 4 to 6 weeks earlier the following spring. There was no enhancement in bermudagrass quality by temporarily covering at predicted night temperatures of $\leq 15$ or $\leq 9.5^{\circ} \mathrm{C}$. Foliar applied iron $(\mathrm{Fe})$ further enhanced turf quality in the fall and winter months, but resulted in no visible turf response the following spring. Total nonstructural carbohydrate (TNC) concentrations in rhizomes that were sampled during November, January, and April 2000 and 2001 were generally increased by the cover application as compared to the uncovered control. Foliar Fe applications did not influence TNC levels.
\end{abstract}

Covers of various compositions are routinely applied to protect from extreme cold and moisture stress, and to enhance turf establishment. Polyester, polypropylene, and pine needle covers have reduced winter desiccation, and polyester blankets have enhanced spring green-up of creeping bentgrass (Agrostis stolonifera L.) by 5 to $12 \mathrm{~d}$ (Roberts, 1986). Winter survival of bermudagrass [Cynodon dactylon (L.) Pers. $\times$ transvaalensis Burtt-Davy] in Kentucky was enhanced by applying straw, polypropylene or polyester covers (Tapp et al., 1988). In Maryland, Sowers and Welterlen (1988) reported that August and September bermudagrass plantings that remained under plastic throughout the winter exhibited higher bermudgrass winter survival as compared to either unmulched or straw-mulched plots the following year. Shashikumar and Nus (1993) observed that a spun-bonded cover improved cold acclimation and increased crown moisture

Received for publication 9 Apr. 2003. Accepted for publication 15 Feb. 2004. Paper no. J10337 of the Mississippi Agriculture and Forestry Experiment Station. Thanks to Pat Gerard for statistical advice and Wayne Langford, Wayne Philley, and Pat Sneed for assistance in field research. Mention of a trademark, proprietary product, or vendor does not constitute a guarantee or warranty of the product by Mississippi State University and does not imply its approval to the exclusion of other products or vendors that also may be suitable.

${ }^{1}$ Professor; current position Associate professor, turfgrass extension specialist, Dept. of Crop, Soil, and Env. Sci., Virginia Tech, Blacksburg, VA 24061.

${ }^{2}$ Postdoctoral associate, GeoResources Institute.

${ }^{3}$ Associate professor.

${ }^{4}$ Research associate II.

${ }^{5}$ Assistant professor. content of bermudagrass in Kansas. Under limited snowfall on an annual bluegrass (Poa аппиа L.) golf green, applications of curled wood mat, straw mulch, and a $5-\mathrm{cm}$ air pocket under an impermeable cover effectively reduced crown temperature variation and raised minimum low temperatures (Dionne et al., 1999). Johnston and Golob (1997) reported that turf covers applied to a green comprised of creeping bentgrass and annual bluegrass reduced winter desiccation problems.

In addition to the use of covers, foliar iron applications are reported to improve bermudagrass color and growth when applied late in the growing season. White and Schmidt (1990) reported that foliar applied Fe extended turf quality during the fall without adversely affecting bermudagrass postdormancy recovery. Foliar iron also improved fall color and enhanced next-summer transplant establishment of bermudagrass propagules (Schmidt and Chalmers, 1993).

Total nonstructural carbohydrate levels (TNC) in bermudagrass are reported to increase in the fall as hardening of the turf occurs (Dunn and Nelson, 1974), but there is no research published that cites the effects of using covers to extend the bermudagrass growing period on TNC concentrations. There are numerous reports detailing varying effects of $\mathrm{N}$ fertilization on $\mathrm{TNC}$ levels ranging from decreases (Trenholm, 1998), to little to no effect (Goatley et al., 1994, 1998), to effects that depended on seasonal N totals (Munshaw et al., 2002)

The primary reason for covering bermudagrass turfs in the southern United States is protection from potentially lethal low temperatures. Permanently installed covers (synthetic or natural materials) are still used by some golf and sports turf facilities for the duration of winter weather. However, since winter temperatures in this region are often conducive to outdoor sports, the practice of permanently covering bermudagrass turfs for winter protection is usually unacceptable. Much of the southern U.S. golf industry has adopted a strategy of temporarily covering their bermudagrass golf greens prior to and during periods of extreme temperatures that might kill the grass. This affords some degree of protection from winter damage, allows play to continue when temperatures moderate, and minimizes the chances of accelerating bermudagrass growth when the possibility of damaging cold temperatures still exists.

This research was conducted on a simulated bermudagrass sports field with play continuing through periods of reduced turf growth. The research objectives were as follows: 1) determine if the use of a temporary turf cover, with and without foliar applied Fe, would maintain acceptable bermudagrass color during the fall and winter months, and improve spring greenup; 2) determine a nighttime temperature range where the application of a temporary cover was beneficial at maintaining bermudagrass color; and 3) determine effects of the cover and $\mathrm{Fe}$ treatments on total nonstructural carbohydrate levels (TNC) in bermudagrass rhizomes harvested in the winter and early spring months.

\section{Materials and Methods}

Research was conducted at the Mississippi State University Plant Science Research Center from September through April 1998-99, 1999-2000, and 2000-01. Bermudagrass $[$ Cynodon dactylon $($ L.) Pers. $\times$ transvaalensis Burtt-Davy 'Tifway'] turf grown on a Marietta fine loam (fine loamy, siliceous thermic Fluvaquentic eutrochrept, $\mathrm{pH}$ of 6.3) was used. The turf received $49 \mathrm{~kg} \cdot \mathrm{ha}^{-1}$ of $\mathrm{N}$ monthly from May through October with the fertilizer sources alternating between either 13-13-13 (containing $13 \% \mathrm{~N}, 5.7 \% \mathrm{P}$, and $10.4 \% \mathrm{~K}$ ) and $34-0-0$. The turf was mowed three times per week at 2-cm using a commercially available reel mower and was irrigated as necessary to maintain active growth. All clippings were returned to the plots. Simazine [2-chloro-4,6bis(ethylamino-s-triazine) was applied according to label recommendations at the level of $2.2 \mathrm{~kg} \cdot \mathrm{ha}^{-1}$ active ingredient in the first week of October in each trial for weed control. Turf blankets (Typar white, spunbonded polypropylene, \#32N01, passing 70\% photosynthetically active radiation; manufactured by Reemay, Inc., Old Hickory, Tenn.) were applied to the bermudagrass plots in the fall and early winter months when nighttime temperatures were predicted to be in the specific temperature treatment range [National Weather Service local forecast (www.weather.com)]. The specific temperature treatment range for covering was $\leq 15, \leq 9.5$, or $\leq 4{ }^{\circ} \mathrm{C}$, and an uncovered control. The covers were removed from the turf by midmorning of the following day unless daytime 
Table 1 . The number of seasonal covering events from trial initiation until loss of acceptable bermudagrass quality in 1998,1999 , and 2000 according to predicted night temperatures of $\leq 15, \leq 9.5$, and $\leq 4{ }^{\circ} \mathrm{C}$.

Predicted

\begin{tabular}{|c|c|c|c|c|c|c|c|c|c|c|c|c|c|c|c|}
\hline \multirow{2}{*}{$\begin{array}{l}\text { temp } \\
\left({ }^{\circ} \mathrm{C}\right)\end{array}$} & \multicolumn{5}{|c|}{1998} & \multicolumn{5}{|c|}{1999} & \multicolumn{5}{|c|}{2000} \\
\hline & Sept. & Oct. & Nov. & Dec. & Total $^{y}$ & Sept. & Oct. & Nov. & Dec. & Total & Sept. & Oct. & Nov. & Dec. & Total \\
\hline$\leq 15$ & 3 & 16 & 29 & 4 & 52 & 14 & 26 & 29 & 17 & 86 & 9 & 31 & 29 & 12 & 81 \\
\hline$\leq 9.5$ & 0 & 12 & 21 & 3 & 36 & 4 & 18 & 22 & 13 & 57 & 3 & 12 & 21 & 12 & 48 \\
\hline$\leq 4$ & 0 & 5 & 7 & 0 & 12 & 0 & 4 & 11 & 6 & 21 & 0 & 6 & 16 & 12 & 34 \\
\hline
\end{tabular}

${ }^{\mathrm{z}} \mathrm{A}$ Typar turf blanket was applied to the turf at these respective ranges based on night temperatures predicted by the National Weather Service.

y Total number of covering dates according to the predicted temperature until bermudagrass quality ratings were deemed unacceptable using a scale of 1 to 9 where 1 = totally brown turf, $6=$ minimal acceptable quality regarding color and uniformity, to $9=$ dark green, highly uniform turf. Acceptable turf quality was observed through 4 Dec. 1998, 17 Dec. 1999, and 12 Dec. 2000. Total possible covering dates from initiation of trial to unacceptable turf quality ratings due to frost damage was $95 \mathrm{~d}$ in 1998, $108 \mathrm{~d}$ in 1999, and $103 \mathrm{~d}$ in 2000.

temperatures were not predicted to exceed the lowest cover temperature treatment of $4{ }^{\circ} \mathrm{C}$. Once the bermudagrass under the turf blanket lost all green color, covers were applied to the plots and remained in place regardless of predicted temperatures until $100 \%$ bermudagrass green-up occurred. After complete greening in the spring, the covers were applied and removed according to the temperature treatments previously described.

Beginning in mid-September of each year, weekly foliar applications of $2.5 \mathrm{~kg} \cdot \mathrm{ha}^{-1} \mathrm{Fe}$ with a popular, commercially available product (Ferromec, $15-0-0$, containing $4 \% \mathrm{~S}$ and $6 \%$ Fe by weight; manufactured by PBI/Gordon Corporation, Kansas City, Mo.) were made to one-half of the bermudagrass plots across the cover treatments. The Fe was applied using water as the carrier at a total volume delivered of $254 \mathrm{~L} \cdot \mathrm{ha}^{-1}$ at $240 \mathrm{kPa}$. The weekly Fe applications were made through the first week of November in each year, providing a total of $22.5 \mathrm{~kg} \cdot \mathrm{ha}^{-1} \mathrm{Fe}$ to the treated turf. Though the Ferromec was applied at labeled rates appropriate for a micronutrient, by the end of the 9-week Ferromecapplication period, there was a difference of $48 \mathrm{~kg} \cdot \mathrm{ha}^{-1} \mathrm{~N}$ and $13 \mathrm{~kg} \cdot \mathrm{ha}^{-1} \mathrm{~S}$ between treated and untreated plots. No attempts were made to adjust the difference in $\mathrm{N}$ and $\mathrm{S}$ levels between the Ferromec treated and untreated plots.

Visual quality ratings were made periodically during the fall and winter months using a scale of 1 to 9 (where 1 = totally brown turf, to $6=$ minimal acceptable quality regarding color and uniformity, to $9=$ dark green, highly uniform turf). Following the loss of turfgrass color from cold temperature damage in the cover treatment plots, visual percent greenup ratings were periodically made until the turf reached $100 \%$ green cover. Rhizome samples were collected in November, January, and April in the 1999-2000 and 2000-01 trials. To test total nonstructural carbohydrate levels, rhizome samples were separated by removing two 5-cm-diameter plugs of bermudagrass from each cover and Fe combination subplot, washing the soil from the samples, and trimming and removing the roots and verdure. Once completed, rhizomes were collected and dried in an air-forced oven at $100{ }^{\circ} \mathrm{C}$ for one hour followed by drying at $70{ }^{\circ} \mathrm{C}$ for at least 48 hours. The samples were then stored in a freezer at $-5{ }^{\circ} \mathrm{C}$ until total nonstructural carbohydrate extraction according to the enzyme extraction method of Smith (1981).

The experimental design was a strip plot with each cover temperature treatment (the whole plot) replicated four times. A mixed model ANOVA was performed on the data and mean separations were made by LSD calculations $(p \leq 0.05)$ when appropriate (SAS Institute, Cary, N.C.). Where Fe by cover treatment interactions were determined, pairwise comparisons between Fe treatments across cover temperature treatments were made.

\section{Results and Discussion}

The average first killing frost date in the Starkville, Miss., area is 6 Nov. (Anonymous, 1973). During the 3 years of this study, the first killing frost dates were 5 Nov. 1998, 3 Nov. 1999,

Table 2. Visual quality ratings of 'Tifway' bermudagrass in Fall 1998 through January 1999 following applications of iron $(\mathrm{Fe})$ and temporary covers applied according to predicted night temperatures.

\begin{tabular}{|c|c|c|c|c|c|}
\hline $\begin{array}{l}\text { Fe level } \\
\left(\mathrm{kg} \cdot \mathrm{ha}^{-1}\right)\end{array}$ & $\leq 4{ }^{\circ} \mathrm{C}^{\mathrm{z}, \mathrm{y}, \mathrm{x}}$ & $\leq 9^{\circ} \mathrm{C}$ & $\leq 15^{\circ} \mathrm{C}$ & Uncovered & $\begin{array}{c}\text { Mean across } \\
\text { cover treatment }^{\mathrm{w}}\end{array}$ \\
\hline \multicolumn{6}{|l|}{16 Oct. } \\
\hline 0 & $6.1 \mathrm{~b}$ & $6.4 \mathrm{~b}$ & $6.3 \mathrm{~b}$ & $5.6 \mathrm{~b}$ & $\begin{array}{c}6.1 \\
*\end{array}$ \\
\hline 2.4 & $7.5 \mathrm{a}$ & $7.4 \mathrm{a}$ & $7.5 \mathrm{a}$ & $7.0 \mathrm{a}$ & 7.3 \\
\hline $\begin{array}{l}\text { Mean across Fe } \\
\text { treatment }^{\mathrm{v}}(\mathrm{LSD}=0.5)\end{array}$ & $6.8 \mathrm{AB}$ & $6.9 \mathrm{~A}$ & $6.9 \mathrm{~A}$ & $6.3 \mathrm{~B}$ & \\
\hline \multicolumn{6}{|l|}{30 Oct. } \\
\hline 0 & $5.5 \mathrm{~b}$ & $5.8 \mathrm{~b}$ & $6.5 \mathrm{~b}$ & $5.1 \mathrm{~b}$ & $\begin{array}{c}5.7 \\
*\end{array}$ \\
\hline 2.4 & $7.0 \mathrm{a}$ & $6.9 \mathrm{a}$ & $7.8 \mathrm{a}$ & $6.1 \mathrm{a}$ & 6.9 \\
\hline $\begin{array}{l}\text { Mean across Fe } \\
\text { treatment }^{v}(\mathrm{LSD}=0.6)\end{array}$ & $6.3 \mathrm{~B}$ & $6.3 \mathrm{~B}$ & $7.1 \mathrm{~A}$ & $5.6 \mathrm{C}$ & \\
\hline \multicolumn{6}{|l|}{13 Nov. } \\
\hline 0 & $6.5 \mathrm{~b}$ & $6.6 \mathrm{~b}$ & $6.7 \mathrm{~b}$ & $4.0 \mathrm{a}$ & $\begin{array}{c}6.0 \\
*\end{array}$ \\
\hline 2.4 & $7.6 \mathrm{a}$ & $7.5 \mathrm{a}$ & $7.8 \mathrm{a}$ & $4.8 \mathrm{~b}$ & 6.9 \\
\hline $\begin{array}{l}\text { Mean across Fe } \\
\text { treatment }^{\mathrm{v}}(\mathrm{LSD}=0.5)\end{array}$ & $7.1 \mathrm{~A}$ & $7.1 \mathrm{~A}$ & $7.4 \mathrm{~A}$ & $4.4 \mathrm{~B}$ & \\
\hline \multicolumn{6}{|l|}{8 Dec. } \\
\hline 0 & $6.8 \mathrm{~b}$ & $7.3 \mathrm{~b}$ & $7.4 \mathrm{~b}$ & $5.1 \mathrm{~b}$ & $\begin{array}{c}6.6 \\
*\end{array}$ \\
\hline 2.4 & $7.9 \mathrm{a}$ & $8.0 \mathrm{a}$ & $8.0 \mathrm{a}$ & $6.5 \mathrm{a}$ & 7.6 \\
\hline $\begin{array}{l}\text { Mean across Fe } \\
\text { treatment }^{\mathrm{v}}(\mathrm{LSD}=0.6)\end{array}$ & $7.3 \mathrm{~A}$ & $7.6 \mathrm{~A}$ & $7.7 \mathrm{~A}$ & $5.8 \mathrm{~B}$ & \\
\hline \multicolumn{6}{|l|}{3 Jan. } \\
\hline 0 & $6.9 \mathrm{~b}$ & $7.1 \mathrm{~b}$ & $7.4 \mathrm{~b}$ & $5.6 \mathrm{~b}$ & $\begin{array}{c}6.8 \\
*\end{array}$ \\
\hline 2.4 & $8.3 \mathrm{a}$ & $8.3 \mathrm{a}$ & $8.4 \mathrm{a}$ & $7.0 \mathrm{a}$ & 8.0 \\
\hline $\begin{array}{l}\text { Mean across Fe } \\
\text { treatment }^{\mathrm{v}}(\mathrm{LSD}=0.6)\end{array}$ & $7.6 \mathrm{~A}$ & $7.7 \mathrm{~A}$ & $7.9 \mathrm{~A}$ & $6.3 \mathrm{~B}$ & \\
\hline
\end{tabular}

${ }^{\mathrm{z}} \mathrm{A}$ Typar turf blanket was applied to the turf at these respective ranges based on night temperatures predicted by the National Weather Service.

y Visual quality ratings based on a scale of 1 to 9 where $1=$ totally brown turf, $6=$ minimal acceptable quality regarding color and uniformity, to $9=$ dark green, highly uniform turf.

${ }^{x}$ Turf quality means between $\mathrm{Fe}$ treatments within the same cover temperature and rating date followed by the same lower case letter are not significantly different at $P \leq 0.05$ level according to LSD tests.

wTurf quality means within a date between Fe treatments averaged across cover treatments are significantly different (*) at $P \leq 0.05$ according to LSD tests.

vTurf quality means within a date between cover temperature treatments averaged across Fe treatments followed by the same upper case letter are not significantly different at $P \leq 0.05$ according to LSD tests. 
On average, covers had to be applied to the $\leq 15$ ${ }^{\circ} \mathrm{C}$ treatment $69 \%$ of the time, to the $\leq 9.5{ }^{\circ} \mathrm{C}$ treatment $48 \%$ of the time, and to the $\leq 4{ }^{\circ} \mathrm{C}$ treatment $24 \%$ of the covering period.

Bermudagrass quality as affected by foliar iron applications. For both covered and uncovered treatments, foliar Fe applications significantly enhanced and helped maintain bermudagrass color (Tables 2, 3, and 4). These findings are supported by White and Schmidt (1989) who reported that foliar iron applications helped maintain physiological activity and resulted in more desirable turf quality of bermudagrass when exposed to chilling temperatures. The quality ratings following Fe treatment recorded early in each season's trial likely reflect a color response due to the $\mathrm{Fe}$ application, but as the levels of $\mathrm{N}$ and $\mathrm{S}$ increased due to the weekly treatments of the Ferromec product, there is no way to clearly distinguish the contribution of $\mathrm{N}$ and $\mathrm{S}$ to the quality ratings. Late-season $\mathrm{N}$ applications have been shown to promote both fall and spring bermudagrass color without negatively affecting freeze tolerance (Goatley et al., 1994; Richardson, 2002). However, we believe the additional $48 \mathrm{~kg} \cdot \mathrm{ha}^{-1} \mathrm{~N}$ and $13 \mathrm{~kg} \cdot \mathrm{ha}^{-1} \mathrm{~S}$ from the Ferromectreatment (in addition to a total of $294 \mathrm{~kg} \cdot \mathrm{ha}^{-1} \mathrm{~N}$ delivered in monthly fertilization events from May to Oct.) were not significantly large enough application rates to confound the experimental results on the basis of quantifying Fe effects. The Ferromec application to the uncovered control plots did not maintain minimal acceptable turf quality ratings when the turf was subjected to killing frost. On 13 Nov. 1998 and 18 Oct. 2000, frost damage in the uncovered plots resulted in quality ratings less than the minimal acceptable level regardless of whether Fe was applied. However, as the weather warmed and the turf resumed growth, each of the Fe-treated plots returned to at least minimal acceptable levels of quality (Tables 2 and 4). On 3 Nov. 1999 the killing frost resulted in unacceptable turf quality ratings in the uncovered controls, regardless of Fe treatment. At that time, and for that particular fall season, turf quality did not return to minimal acceptable levels (Table 3). There was no visible postdormancy enhancement of bermudagrass color, quality, or spring greenup in any year from the Ferromec treatment. This supports our contention that the short term greening effect of the $\mathrm{Fe}$ application was primarily responsible for the color response in fall and early winter rating dates.

Bermudagrass quality as affected by application of covers. At all rating dates except for 11, 18, and 25 Oct. 2000 there were no Fe by cover treatment interactions during the fall and winter rating periods. All temperaturebased cover treatments maintained acceptable bermudagrass quality through 3 Jan. 1999 in the 1998-99 trial, and through 17 Dec. 1999 and 12 Dec. 2000 in the 1999-2000 and 2000-01 trials, respectively (Tables 2, 3, and 4). As previously discussed, the combination of $\mathrm{Fe}$ with the cover treatment further enhanced late fall and early winter bermudagrass color. Differences in turf quality between the cover temperature treatments were observed at five measurement dates (30 Oct. 1998, 7 and 21 Oct. 1999, and 18 Oct. and 1 Nov. 2000) across

the 20 color rating dates in the 3 years' trials. However, even when there were differences

Table 3. Visual quality ratings of 'Tifway' bermudagrass in Fall 1999 following applications of iron (Fe) and temporary covers applied according to predicted night temperatures.

\begin{tabular}{lccccc}
\hline $\begin{array}{l}\text { Fe level } \\
\left(\mathrm{kg}^{-1} a^{-1}\right)\end{array}$ & $\leq 4{ }^{\circ} \mathrm{C}^{\mathrm{z}, \mathrm{y}, \mathrm{x}}$ & $\leq 9{ }^{\circ} \mathrm{C}$ & $\leq 15^{\circ} \mathrm{C}$ & Uncovered & $\begin{array}{c}\text { Mean across } \\
\text { cover treatment }^{\mathrm{w}}\end{array}$ \\
\hline 7 Oct. & & & & & 7.8 \\
0 & 7.3 & 8.0 & 8.5 & 7.3 & $\mathrm{NS}$ \\
& $\mathrm{NS}$ & $\mathrm{NS}$ & $\mathrm{NS}$ & $\mathrm{NS}$ & 7.7 \\
2.4 & 7.3 & 8.0 & 8.3 & 7.4 & \\
Mean across Fe & $7.3 \mathrm{~B}$ & $8.0 \mathrm{~A}$ & $8.4 \mathrm{~A}$ & $7.3 \mathrm{~B}$ & \\
$\begin{array}{l}\text { treatment } \\
\text { 14 Oct. }\end{array}$ & & & & & 7.3 \\
0 & 7.6 & 7.5 & 7.0 & 7.3 & $\mathrm{NS}$ \\
& $\mathrm{NS}$ & $\mathrm{NS}$ & $\mathrm{NS}$ & $\mathrm{NS}$ & 7.8 \\
2.4 & 8.0 & 7.9 & 7.5 & 7.9 & \\
Mean across Fe & $7.8 \mathrm{~A}$ & $7.7 \mathrm{AB}$ & $7.3 \mathrm{~B}$ & $7.6 \mathrm{AB}$ &
\end{tabular}

treatment $^{\mathrm{v}}(\mathrm{LSD}=0.4)$

21 Oct.

0

2.4

\section{4}

Mean across $\mathrm{Fe}$

treatment ${ }^{\mathrm{v}}(\mathrm{LSD}=0.3)$

29 Oct.

0

2.4

Mean across Fe

$6.9 \mathrm{~b}$

(1.7.

$7.3 \mathrm{~B}$

7.6 $\mathrm{AB}$

treatment $^{\mathrm{v}}(\mathrm{LSD}=0.4)$

4 Nov.

0

2.4

Mean across $\mathrm{Fe}$

treatment ${ }^{\mathrm{v}}(\mathrm{LSD}=0.9)$

12 Nov.

0

\section{4}

Mean across $\mathrm{Fe}$

treatment $^{\mathrm{v}}(\mathrm{LSD}=0.9)$

19 Nov.

0

\section{4 \\ Mean across $\mathrm{Fe}$}

treatment ${ }^{v}(\mathrm{LSD}=0.7)$

1 Dec.

0

$$
2.4
$$

Mean across $\mathrm{Fe}$

$$
7.5 \mathrm{a}
$$

$6.9 \mathrm{~b}$

$6.3 \mathrm{~b}$

$7.6 \mathrm{a}$

$7.0 \mathrm{a}$

$6.6 \mathrm{~b}$

$6.6 \mathrm{~B}$

$7.4 \mathrm{a}$

$7.0 \mathrm{~A}$

6.7

$7.3 \mathrm{~A}$

6.6 b

\section{$7.0 \mathrm{~b}$}

$6.6 \mathrm{~b}$

$7.9 \mathrm{a}$

$7.6 \mathrm{a}$

$8.1 \mathrm{a}$

7.4 AB

$7.1 \mathrm{~B}$

$5.6 \mathrm{~b}$

$6.5 \mathrm{a}$

$6.1 \mathrm{C}$

$7.4 \mathrm{~b}$

$$
7.4 \mathrm{~b}
$$

$7.1 \mathrm{~b}$

$3.5 \mathrm{~b}$

$8.1 \mathrm{a}$

$8.4 \mathrm{a}$

$8.3 \mathrm{a}$

$7.9 \mathrm{~A}$

$7.8 \mathrm{~A}$

$7.6 \mathrm{~A}$

$4.9 \mathrm{a}$

$4.2 \mathrm{~B}$

treatment ${ }^{\mathrm{v}}(\mathrm{LSD}=0.9)$

9 Dec.

0

2.4

Mean across $\mathrm{Fe}$

$7.4 \mathrm{~b}$

$7.3 \mathrm{~b}$

$6.9 \mathrm{~b}$

$8.5 \mathrm{a}$

$7.9 \mathrm{~A}$

$8.5 \mathrm{a}$

$7.8 \mathrm{~A}$

$7.7 \mathrm{~A}$

$3.6 \mathrm{~b}$

$5.3 \mathrm{a}$

$4.4 \mathrm{~B}$

$7.6 \mathrm{~b}$

$7.6 \mathrm{~b}$

$7.6 \mathrm{~b}$

$4.0 \mathrm{~b}$

6.7

$8.4 \mathrm{a}$

$8.3 \mathrm{a}$

$8.4 \mathrm{a}$

$5.6 \mathrm{a}$

$4.8 \mathrm{~B}$

7.7

treatment ${ }^{\mathrm{v}}(\mathrm{LSD}=0.5)$

17 Dec.

0

2.4
Mean across Fe

8.0

$7.9 \mathrm{~A}$

$8.0 \mathrm{~A}$

$7.0 \mathrm{~b}$

$7.3 \mathrm{~b}$

$8.0 \mathrm{a}$

$8.1 \mathrm{a}$

$2.3 \mathrm{~b}$

5.8

$3.8 \mathrm{a}$

$3.0 \mathrm{~B}$

treatment $^{\mathrm{v}}(\mathrm{LSD}=0.5)$

${ }^{2} \mathrm{~A}$ Typar turf blanket was applied to the turf at these respective ranges based on night temperatures predicted by the National Weather Service.

${ }^{y}$ Visual quality ratings based on a scale of 1 to 9 where $1=$ totally brown turf, $6=$ minimal acceptable quality regarding color and uniformity, to $9=$ dark green, highly uniform turf.

${ }^{x}$ Turf quality means between Fe treatments within the same cover temperature and rating date followed by the same lower case letter are not significantly different at $P \leq 0.05$ level according to LSD tests. NS = nonsignificant.

wTurf quality means within a date between Fe treatments averaged across cover treatments are significantly different $(*)$ at $P \leq 0.05$ according to LSD tests. NS $=$ nonsignificant.

vTurf quality means within a date between cover temperature treatments averaged across Fe treatments followed by the same upper case letter are not significantly different at $P \leq 0.05$ according to LSD tests. 
in mean quality ratings between the cover temperature treatments, the differences were small. Thus, we believe that under our environmental and experimental conditions, it is not necessary to apply a temporary cover such as

the Typar turf blanket for the maintenance of bermudagrass quality and color until predicted night temperatures of $\leq 4{ }^{\circ} \mathrm{C}$ occur.

Although not measured as a treatment response, it was observed that while desirable

Table 4. Visual quality ratings of 'Tifway' bermudagrass in Fall 2000 following applications of iron (Fe) and temporary covers applied according to predicted night temperatures.

\begin{tabular}{|c|c|c|c|c|c|}
\hline $\begin{array}{l}\text { Fe level } \\
\left(\mathrm{kg}^{\prime} \mathrm{ha}^{-1}\right)\end{array}$ & $\leq 4{ }^{\circ} \mathrm{C}^{\mathrm{z}, \mathrm{y}, \mathrm{x}}$ & $\leq 9{ }^{\circ} \mathrm{C}$ & $\leq 15^{\circ} \mathrm{C}$ & Uncovered & $\begin{array}{l}\text { LSD for comparing } \\
\text { cover treatment means } \\
\text { within an Fe treatment }\end{array}$ \\
\hline \multicolumn{6}{|l|}{11 Oct. } \\
\hline 0 & $\begin{array}{c}6.8 \mathrm{~B} \\
*\end{array}$ & $\begin{array}{c}7.1 \mathrm{AB} \\
*\end{array}$ & $\begin{array}{l}7.4 \mathrm{~A} \\
*\end{array}$ & $\begin{array}{l}5.5 \mathrm{C} \\
*\end{array}$ & 0.5 \\
\hline 2.4 & $7.3 \mathrm{~B}$ & $7.5 \mathrm{AB}$ & $7.8 \mathrm{~A}$ & $6.5 \mathrm{C}$ & 0.5 \\
\hline \multicolumn{6}{|l|}{18 Oct. } \\
\hline 0 & $\begin{array}{c}7.0 \mathrm{~B} \\
*\end{array}$ & $\begin{array}{c}7.4 \mathrm{AB} \\
*\end{array}$ & $\begin{array}{c}8.0 \mathrm{~A} \\
*\end{array}$ & $\begin{array}{c}3.8 \mathrm{C} \\
*\end{array}$ & 0.6 \\
\hline 2.4 & $7.6 \mathrm{~B}$ & $8.0 \mathrm{AB}$ & $8.6 \mathrm{~A}$ & $5.4 \mathrm{C}$ & 0.7 \\
\hline \multicolumn{6}{|l|}{25 Oct. } \\
\hline 0 & $\begin{array}{c}6.6 \mathrm{~A} \\
*\end{array}$ & $\begin{array}{l}6.9 \mathrm{~A} \\
*\end{array}$ & $\begin{array}{l}7.3 \mathrm{~A} \\
*\end{array}$ & $\begin{array}{l}4.9 \mathrm{~B} \\
*\end{array}$ & 1.0 \\
\hline 2.4 & $7.3 \mathrm{~A}$ & $7.4 \mathrm{~A}$ & $7.9 \mathrm{~A}$ & $6.0 \mathrm{~B}$ & $\begin{array}{c}1.0 \\
\text { Mean across } \\
\text { cover treatment }{ }^{\mathrm{v}}\end{array}$ \\
\hline \multicolumn{6}{|l|}{1 Nov." } \\
\hline 0 & $7.0 \mathrm{~b}$ & $7.4 \mathrm{~b}$ & $7.3 \mathrm{~b}$ & $6.8 \mathrm{~b}$ & $\begin{array}{c}7.1 \\
*\end{array}$ \\
\hline 2.4 & $7.6 \mathrm{a}$ & $8.0 \mathrm{a}$ & $7.8 \mathrm{a}$ & $7.5 \mathrm{a}$ & 7.7 \\
\hline $\begin{array}{l}\text { Mean across Fe } \\
\text { treatment }^{\prime}(\mathrm{LSD}=0.4) \\
15 \text { Nov. }\end{array}$ & $7.3 \mathrm{AB}$ & $7.7 \mathrm{~A}$ & $7.5 \mathrm{AB}$ & $7.1 \mathrm{~B}$ & \\
\hline \multirow[t]{2}{*}{0} & 6.8 & 6.8 & 6.7 & 1.9 & 5.5 \\
\hline & NS & NS & NS & NS & NS \\
\hline 2.4 & 7.2 & 7.4 & 7.1 & 2.3 & 5.9 \\
\hline $\begin{array}{l}\text { Mean across Fe } \\
\text { treatment }(\mathrm{LSD}=0.5) \\
12 \text { Dec. }\end{array}$ & $7.0 \mathrm{~A}$ & $7.1 \mathrm{~A}$ & $6.9 \mathrm{~A}$ & $2.0 \mathrm{~B}$ & \\
\hline 0 & 6.3 & 6.4 & 6.2 & 1.5 & 5.1 \\
\hline & NS & NS & NS & NS & NS \\
\hline 2.4 & 6.6 & 6.6 & 6.6 & 2.0 & 5.5 \\
\hline $\begin{array}{l}\text { Mean across Fe } \\
\text { treatment }^{t}(\mathrm{LSD}=0.5)\end{array}$ & $6.4 \mathrm{~A}$ & $6.5 \mathrm{~A}$ & $6.4 \mathrm{~A}$ & $1.8 \mathrm{~B}$ & \\
\hline
\end{tabular}

${ }^{\mathrm{z}} \mathrm{A}$ Typar turf blanket was applied to the turf at these respective ranges based on night temperatures predicted by the National Weather Service.

y Visual quality ratings based on a scale of 1 to 9 where $1=$ totally brown turf, $6=$ minimal acceptable quality regarding color and uniformity, to $9=$ dark green, highly uniform turf.

${ }^{x}$ Turf quality means within a date within a cover treatment between Fe treatments are significantly different (*) at $P \leq 0.05$ according to LSD tests.

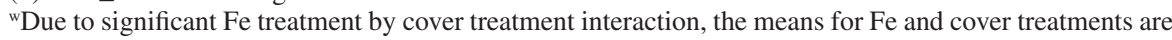
analyzed accordingly. Turf quality means within a date within an Fe treatment followed by the same upper case letter are not significantly different at $P \leq 0.05$ according to LSD tests.

'Turf quality means within a date within a cover treatment between Fe treatments are significantly different $(*)$ at $P \leq 0.05$ according to LSD tests.

uTurf quality means between $\mathrm{Fe}$ treatments within the same cover temperature and rating dates of 1 and 15 Nov. and 12 Dec. followed by the same lower case letter are not significantly different at $P \leq 0.05$ level according to LSD tests. NS = nonsignificant.

'Turf quality means within the dates of 1 and 15 Nov. and 12 Dec. between cover treatments averaged across Fe treatments followed by the same upper case letter are not significantly different at $P \leq 0.05$ according to LSD tests.

Table 5. Total nonstructural carbohydrate (TNC) concentrations in 'Tifway' bermudagrass rhizomes as affected by applying temporary covers according to various predicted night temperatures.

\begin{tabular}{lcccccc}
\hline & \multicolumn{5}{c}{ TNC concn $\left(\mathrm{g} \cdot \mathrm{kg}^{-1}\right)$} \\
\cline { 2 - 7 } Cover & November $^{y}$ & January & April & November & January & April \\
temp & 1999 & 2000 & 2000 & 2000 & 2001 & 2001 \\
\hline Uncovered & 15.6 & 9.6 & $11.1 \mathrm{~b}$ & $10.5 \mathrm{~b}$ & $15.4 \mathrm{~b}$ & $7.8 \mathrm{c}$ \\
$\leq 4{ }^{\circ} \mathrm{C}$ & 14.9 & 11.7 & $15.3 \mathrm{a}$ & $15.1 \mathrm{a}$ & $18.4 \mathrm{a}$ & $14.8 \mathrm{a}$ \\
$\leq 9.5^{\circ} \mathrm{C}$ & 16.6 & 12.4 & $15.1 \mathrm{a}$ & $13.8 \mathrm{a}$ & $18.9 \mathrm{a}$ & $12.9 \mathrm{ab}$ \\
$\leq 15^{\circ} \mathrm{C}$ & 16.9 & 10.5 & $14.3 \mathrm{a}$ & $13.4 \mathrm{a}$ & $17.1 \mathrm{ab}$ & $12.1 \mathrm{~b}$ \\
LSD $(0.05)$ & $\mathrm{NS}$ & $\mathrm{NS}$ & 2.5 & 2.5 & 2.7 & 2.6 \\
\hline
\end{tabular}

${ }^{2}$ A Typar turf blanket was applied to the turf at these respective ranges based on night temperatures predicted by the National Weather Service.

${ }^{y}$ Since Fe treatment did not affect TNC concentration, the means for cover treatments were averaged across Fe treatments. Means followed by the same letter are not significantly different at $P \leq 0.05$ according to LSD tests. NS = Nonsignificant. turf quality was maintained well into at least December in each year's trial, there were very few clippings being removed while mowing the plots from mid-November until bermudagrass dormancy. Bermudagrass growth rate declines rapidly after about $15 \mathrm{Sept}$. in the southern United States, even when well fertilized and irrigated (Burton et al., 1988). Although the temporary application and removal of the covers apparently promoted limited shoot growth during the cooler temperature periods of late fall and early winter, the primary benefit was frost protection. Under all cover treatments, we observed that acceptable turf quality was maintained until temperatures of $\leq-5^{\circ} \mathrm{C}$ occurred for the first time that season (dates of 4 Jan. 1999 for the 1998-99 trial, 17 Dec. 1999, and 12 Dec. 2000 for the respective trials).

Keeping the covers on the plots during the winter months accelerated bermudagrass greenup significantly in all yearly trials without any visible signs of deleterious effects. Similar results were also reported by Sowers and Welterlen, 1988, and Tapp et al., 1988. As recorded in the fall and winter months, there were no differences in turf quality or greenup rates between the three cover temperature treatments. Each covered plot had reached essentially $100 \%$ greenup by 16 Mar., 2 Mar., and 2 Apr. in 1999, 2000, and 2001, respectively. In the uncovered controls across the three years, $100 \%$ greenup was observed by 2 May, 30 Mar., and 5 May in 1999, 2000, and 2001, respectively. Therefore, the maintenance of covers during the winter months accelerated spring bermudagrass greenup by 4 weeks in 2000, and by about 6 weeks in 1999 and 2001 . The maintenance of green turf again depended on the application of the covers for overnight frost protection. In this area of Mississippi, the average last killing frost date for the winter and spring months is 25 Mar. (Anonymous, 1973). As before with fall color ratings, there were essentially no differences in any visible turf quality rating based on the different cover temperature treatments (data not shown). Withholding cover applications until temperatures of $\leq 4{ }^{\circ} \mathrm{C}$ were predicted was satisfactory in maintaining acceptable bermudagrass quality in the late winter and early spring.

Effect of Fe and cover treatments on TNC levels in bermudagrass rhizomes. Foliar $\mathrm{Fe}$ applications had no significant effect on TNC concentration in bermudagrass rhizomes harvested in November, January, or April of the 1999-2000 and 2000-01 covering trials (Table 5). Therefore, the mean TNClevels for Fe-treated and untreated plots were combined for statistical analysis of TNC levels compared between cover temperature treatments. In the 1999-2000 trial there were no significant differences in TNC concentrations until April, when any covering treatment had significantly more TNC reserves. In the 2000-01 trial, all covering treatments except for the $\leq 15^{\circ} \mathrm{C}$ in January 2001 had greater TNC levels than the uncovered control. The only difference in TNC levels between covering treatments occurred in April 2001 when the $\leq 15^{\circ} \mathrm{C}$ treatment had lower concentrations than the $\leq 4$ ${ }^{\circ} \mathrm{C}$ treatment (Table 5).

These data indicate that the application of 
temporary covers did not drain carbohydrate reserves, but instead, generally increased TNC levels. We hypothesize that the grass in the covered plots stored more carbohydrates than the uncovered grass since the duration of a photosynthetically active canopy was extended. Similar results were reported by White and Schmidt $(1989,1990)$.

\section{Conclusions}

Bermudagrass winter hardiness was not compromised by the cover or Fe treatments at any time, even under the environmental pressure of the second coldest December on record in northeast Mississippi during Dec. 2000 as reported by the National Weather Service. These findings continue to support previous research reports that indicate that the enhancement and/or extension of bermudagrass growth periods in the fall and winter months is not a precursor to increased winterkill potential (Goatley et al., 1994; Reeves et al., 1970; Richardson, 2002). Foliar applied Fe extended bermudagrass quality late in the growing season, and its effect was enhanced when combined with a cover. The use of temporary covers when temperatures were predicted to be $\leq 4{ }^{\circ} \mathrm{C}$ extended desirable bermudagrass quality for 5 to 8 weeks after the average fall killing frost date in central Mississippi, and resulted in 4 to 6 weeks earlier greenup the following spring.

Some of the biggest limitations to using covers in this manner are not agronomic in nature, but involve the initial cost of the cover itself, and the manpower and time available to apply and remove the cover repeatedly during periods when play continues but frost potential is great. The application of temporary covers on an extremely high use athletic field will be questionable because of time and labor considerations. However, for the maintenance of acceptable bermudagrass quality during a fall sports season, these data indicate that there is no need to apply covers until night temperatures are predicted to be $\leq 4{ }^{\circ} \mathrm{C}$, and as the data in Table 1 show, this would account on average for only covering the turf $24 \%$ of the time for the extent of a typical American football season in east central Mississippi. Logically, a maintenance program utilizing covers for bermudagrass frost protection would be even more feasible at locales with longer growing seasons than our research site, and cooler climates would have greater need for regular covering events. We anticipate there might be increased weed, disease, and insect pressure under covered bermudagrass turfs, but the early October application of simazine effectively controlled weeds, and there was virtually no disease or insect pressure observed under the covered plots at any time in these trials. Though we did not quantify bermudagrass shoot growth rates, the enhanced spring green-up rates on covered turf will likely result in an earlier mowing requirement as was reported on creeping bentgrass (Johnson and Golob, 1997).

The use of temporary covers presents a viable option to the practice of winter overseeding bermudagrass with Lolium species, a cultural practice that usually produces an aesthetically pleasing turf surface during the winter months, but results in a very weakened bermudagrass canopy after the transition of the cool season grass due to the competition between the species (Horgan and Yelverton, 2001). On minimal use bermudagrass game fields that host only one or two sporting events per week in the southern United States, the application of temporary covers could provide a viable alternative to winter overseeding.

Further research is needed to evaluate and compare other bermudagrass cultivars and other covers of various composition, thicknesses, and colors. Minneret al. (2001) reported that cover color affected Kentucky bluegrass performance and turf quality when left in place for $\geq 32 \mathrm{~d}$. Since no traffic was applied to the plots in our trials, we can not estimate the value of the temporary covers regarding potential turf recovery while being used for sporting events, but we do not anticipate that covering late in the growing season will promote enough bermudagrass regrowth to withstand the rigors of intensive use. Further research is necessary to quantify the effect of covers under heavy traffic conditions. Additionally, an evaluation of the performance of temporary covers for application on bermudagrass golf putting greens is warranted to see if similar responses can be obtained.

\section{Literature Cited}

Anonymous. 1973. Soil Survey of Oktibbeha Co., Miss.

Dionne, J., P. Dubé, M. Laganiére, and Y. Desjardins. 1999. Golf green soil and crown-level temperatures under winter protective covers. Agron. J. 91:227-233.

Burton, G.W., J.E. Hook, J.L. Butler, and R.E. Hellwig. 1988. Effect of temperature, daylength, and solar radiation on production of coastal bermudagrass. Agron. J. 80:557-560.

Goatley, J.M., Jr., V. Maddox, D.J. Lang, and K.K.
Crouse. 1994. 'Tifgreen' bermudagrass response to late-season application of nitrogen and potassium. Agron. J. 86:7-10.

Horgan, B.P. and F.H. Yelverton. 2001. Removal of perennial ryegrass from overseeded bermudagrass using cultural methods. Crop Sci. 41:118-126.

Johnson, W.J. and C.T. Golob. 1997. Using a turf cover in combination with winter applied plant growth regulators on putting greens. Int. Turf. Soc. Res. J., 8:477-483.

Minner, D.D., D. Li, V. Patterozzi, and J.J. Salmond. 2001. The effect of tarp color and cover material on Poa pratensis growth. Int. Turf. Soc. Res. J. 9:328-333.

Munshaw, G.C., D.W. Williams, and P.L. Cornelius. 2001. Management strategies during the establishment year enhance production and fitness of seeded bermudagrass stolons. Crop Sci. 41:1558-1564.

Reeves, Jr., S.A., G.C. McBee, and M.E. Bloodworth. 1970. Effect of N, P, and K tissue levels and late fall fertilization on the cold hardiness of Tifgreen bermudagrass (Cynodon dactylon xtransvaalensis). Agron. J. 62:659-662.

Richardson, M.D. 2002. Turf quality and freezing tolerance of 'Tifway' bermudagrass as affected by late-season nitrogen and trinexapac-ethyl. Crop Sci. 42:1621-1626.

Roberts, J.M. 1986. Influence of protective covers on reducing winter desiccation of turf. Agron. J. 78:145-147.

Schmidt, R.E. and D.R. Chalmers. 1993. Late summer to early fall application of fertilizer and biostimulants on bermudagrass. Intl. Turf. Soc. Res. J. 7:715-721.

Shashikumar, K. and J.L. Nus. 1993. Cultivar and winter cover effects on bermudagrass cold acclimation and crown moisture content. Crop Sci. 33:813-817.

Smith, D. 1981. Removing and analyzing total nonstructural carbohydrates from plant tissue. Wis. Agr. Expt. Stn. Rpt. R2107.

Sowers, R.S. and M.S. Welterlen. 1988. Seasonal establishment of bermudagrass using plastic and straw mulches. Agron. J. 80:144-148.

Trenholm, L.E., A.E. Dudeck, J.B. Sartain, and J.L. Cisar. 1998. Bermudagrass growth, total nonstructural carbohydrate concentration, and quality as influenced by nitrogen and potassium. Crop Sci. 38:168-174.

Tapp, L., A.J. Powell, Jr., and A. Richardson. 1988. Bermudagrass winter management study. Ky. Turf. Res. Progr. Rpt. 319:55-61.

White, R.H. and R.E. Schmidt. 1989. Bermudagrass response to chilling temperatures as influenced by iron and benzyladenine. Crop Sci. 29:768-773

White, R.H. and R.E. Schmidt. 1990. Fall performance and post-dormancy growth of 'Midiron' bermudagrass in response to nitrogen, iron, and benzyladenine. J. Amer. Soc. Hort. Sci. 115:57-61. 